\title{
Regulation of cell fate determination by Skp1-Cullin1-F-box (SCF) E3 ubiquitin ligases
}

\author{
CHRISTOPHER J. HINDLEY ${ }^{1}$, GARY S. MCDOWELL ${ }^{1}$, HELEN WISE $^{1,2}$ and ANNA PHILPOTT* \\ Department of Oncology, University of Cambridge, Hutchison/Medical Research Council (MRC) Research \\ Centre, Addenbrooke's Hospital, Cambridge, U.K.
}

\begin{abstract}
The developing embryo is patterned by a complex set of signals and interactions resulting in changes in cell division, cell fate determination and differentiation. An increasing body of evidence points to the role of the ubiquitin proteasome system (UPS) and ubiquitin-mediated protein degradation as a major mechanism of protein regulation, crucial for control of developmental processes. The specific and irreversible signal generated by protein degradation can function as an integrator of cell signaling events, coupled with other post-translational protein modifications, but also as a master switch for differentiation in its own right. The UPS also displays more subtle mechanisms of regulating signaling than decreasing protein levels, such as proteolytic processing and altering subcellular localization. In particular, the SCF E3 ligase family plays pivotal roles in regulating diverse developmental events in varied species. This review will focus on the role played by SCF E3 ligases in cell fate determination and differentiation.
\end{abstract}

KEY WORDS: differentiation, SCF, signaling, ubiquitylation, UPS

\section{Introduction}

During embryogenesis, individual cells must respond to signaling within the developing embryo and elicit the appropriate response. Such responses involve changes in the level and/or activity of proteins and must be dynamic. Within the field of developmental biology, most emphasis has traditionally been placed on regulation of protein levels by control of transcription. However, it is becoming clear that many proteins are subject to regulated degradation and that this plays a critical regulatory role during embryogenesis. Regulated protein degradation has three key features: irreversibility, responsiveness and selectivity.

Regulated proteolysis of up to $90 \%$ of short-lived proteins is achieved by the ubiquitin proteasome system (UPS) (Ciechanover et al., 1984). Ubiquitin-mediated degradation is initiated by the covalent attachment of ubiquitin (Ub), a 76-amino acid protein, onto a substrate (Ciechanover et al., 1980a; Ciechanover et al., 1980b; Hershko et al., 1980; Wilkinson et al., 1980). Subsequent rounds of ubiquitylation attach additional Ubs to the first to build up a chain; chains of at least 4 Ubs then facilitate the recognition and destruction of the substrate by the $26 \mathrm{~S}$ proteasome (reviewed in Pickart and Cohen, 2004; Wolf and Hilt, 2004).
The addition of Ub onto substrate proteins is catalysed by a multi-enzyme cascade (Fig. 1). Firstly, $\mathrm{Ub}$ is activated using energy from ATP hydrolysis, resulting in the fusion of AMP to the C-terminal carboxyl group. The active site cysteine of an E1 (Ub activating) enzyme can then form a thioester bond with activated $\mathrm{Ub}$. Ub is then passed to the active site cysteine of an E2 (Ub conjugating) enzyme. The last enzyme in the cascade, an E3 (Ub ligase), facilitates the attachment of Ub onto the substrate protein from the E2 enzyme (Hershko et al., 1983; Pickart and Rose, 1985). Successive Ub moieties can be added to the first by a

\footnotetext{
Abbreviations used in this paper: $\mathrm{APC} / \mathrm{C}$, anaphase promoting complex/ cyclosome; Arm, armadillo; bHLH, basic helix-loop-helix; $\beta$-TRCP, $\beta$ transducin repeat containing protein; $\mathrm{Ci}$, Cubitus interruptus; CKI, cyclin dependent kinase inhibitor; Dlg, discs large; dpp, decapentaplegic; Fbw, Fbox protein containing WD40 repeats; Fbx, F-box protein; GCM, glial cells missing; GSK3, glycogen synthase kinase 3; HECT, homologous to E6associated protein C-terminus; Hh, hedgehog; IKK, IкB kinase; MAFbx, muscle atrophy F-box; N $\beta$ T, neural $\beta$-tubulin; NC, neural crest; NF- $\kappa B$, nuclear factor-kB; PKA, protein kinase A; Ppa, partner of paired; Ptc, patched; REST, RE1-silencing transcription factor; RING, really interesting new gene; SCF, Skp1-cullin1-F-box complex; Smo, smoothened; Ub, ubiquitin; UPS, ubiquitin proteasome system.
}

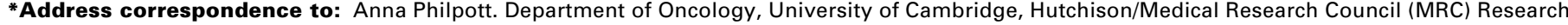
Centre, Addenbrooke's Hospital, Cambridge. CB2 0XZ, UK. Fax: +44-1223-763-241. e-mail:ap113@cam.ac.uk web: http://www.hutchison-mrc.cam.ac.uk/Research/Anna_Philpott/index.html

Note 1: All these authors have contributed equally to this work.

Note 2: Current Address is Department of Pathology, University of Cambridge, Tennis Court Road, Cambridge. CB2 10P, UK.
} 
sequential enzyme cascade. Alternatively, entire polyUb chains may be attached to the substrate protein by the action of an E4 enzyme, such as p300, which has been demonstrated to add chains of polyUb to p53 at sites previously monoubiquitylated by Mdm2 (Grossman et al., 2003; reviewed in Hoppe, 2005). In humans, only 2 E1 enzymes and approximately 100 E2 enzymes have been characterised. By contrast, it is estimated that there may be as many as 1000 E3 ligases (reviewed in Hicke et al., 2005) further divided into 3 classes: Homologous to E6-Associated Protein C-Terminus (HECT), Really Interesting New Gene (RING) and U-box.

Probably the most diverse family is that of the RING E3 ligases; there are almost 400 proteins with RING domains in the human genome, compared to around 38 with HECT domains (Semple, 2003). RING E3 ligases are characterised by the presence of a RING motif (consensus $\mathrm{CX}_{2} \mathrm{CX}_{9-39} \mathrm{CX}_{1-3} \mathrm{HX}_{2-3}[\mathrm{C} / \mathrm{H}] \mathrm{X}_{2} \mathrm{CX}_{4-48} \mathrm{CX}_{2} \mathrm{C}$ ). Based on bioinformatic data, RING E3 ligases can be further divided into single subunit and modular classes. Single subunit RING E3 ligases bind to both E2 enzymes and substrates. In the case of modular RING E3 ligases, the RING protein functions as part of a multi protein complex and substrates are recruited by a separate subunit (reviewed in Deshaies and Joazeiro, 2009). Examples include the Anaphase Promoting Complex/Cyclosome (APC/C) and Cullinbased RING E3 ligases. Cullin-based E3 ligases (reviewed in Petroski and Deshaies, 2005) use the RING protein Roc1 (also known as Rbx1 and Hrt1) to recruit E2 enzymes (Chen et al., 2000; Furukawa et al., 2002; Ohta et al., 1999).

This review will concentrate on the role in development of the most well characterised sub-group of Cullin-based RING E3 ligases, the Skp1-Cullin1-F-box (SCF) E3 ligase complexes. Within the SCF complex, Cullin1 binds to Roc1, Skp1 and a variable F-box protein (Lyapina et al., 1998; Wu et al., 2000), and it is this latter component that confers the SCF complex designation, e.g. SCF ${ }^{\mathrm{Skp} 2}$, where

Fig. 1. Schematic of Ub mediated protein degradation. Ub is first covalently linked to an E1 (Ubactivating) enzyme using energy from ATP hydrolysis before being shuttled to an E2 (Ub-conjugating) enzyme. Ub is then either conjugated directly to a HECT E3 ligase before transfer to the substrate or the E2-Ub is recruited via a RING E3 ligase into a complex containing the substrate. Note that all Ub conjugation from $E 1$ to $E 3$ is via thioester linkage to a cysteine sidechain sulfur. Further attachment of Ub to internal lysines on the original substrate Ub is achieved either by repetition of the above scheme or the action of an E4 enzyme, which transfers polyUb chains to monoubiquitylated substrate ubiquitin. A chain of four or more K48-linked polyUb targets the substrate to the 265 proteasome where it is unfolded and degraded in an ATP-dependent manner into small peptides with concurrent deubiquitylation to recycle Ub.
Skp2 is the F-box component. The SMART database (http:// smart.embl-heidelberg.de/) gives an estimated 56 F-box proteins in humans, 77 in mice and 30-50 in Xenopus laevis, compared to the 600-700 found in the large gene networks of Arabidopsis and rice (Gagne et al., 2002; Jain et al., 2007; Kuroda et al., 2002). In the crystal structure of SCFSkp2 (Schulman et al., 2000; Zheng et al., 2002), which is, to date, the only structure of a complete SCF complex described, Cullin1 forms a rigid, bi-lobed structure which acts as a 'molecular scaffold' on which to assemble the SCF complex. The C-terminal globular domain recruits Roc1, which in turn recruits the E2 enzyme. The Cullin1 N-terminal domain recruits Skp1, which then binds to the F-box protein substrate recognition subunit via interactions between the C-terminus of Skp1 and the F-box domain.

Structural studies are also providing insight into further mechanisms of SCF activity. Many F-box proteins interact with their cognate substrates only after the substrates have been posttranslationally modified, adding an extra level of regulation. Although the most widely reported prior modification is phosphorylation, substrates have also been reported to require acetylation, glycosylation or nitration (Guinez et al., 2008; Hwang et al., 2010). For instance, it is known that degradation of cyclin $\mathrm{E}$ by SCFFbw7

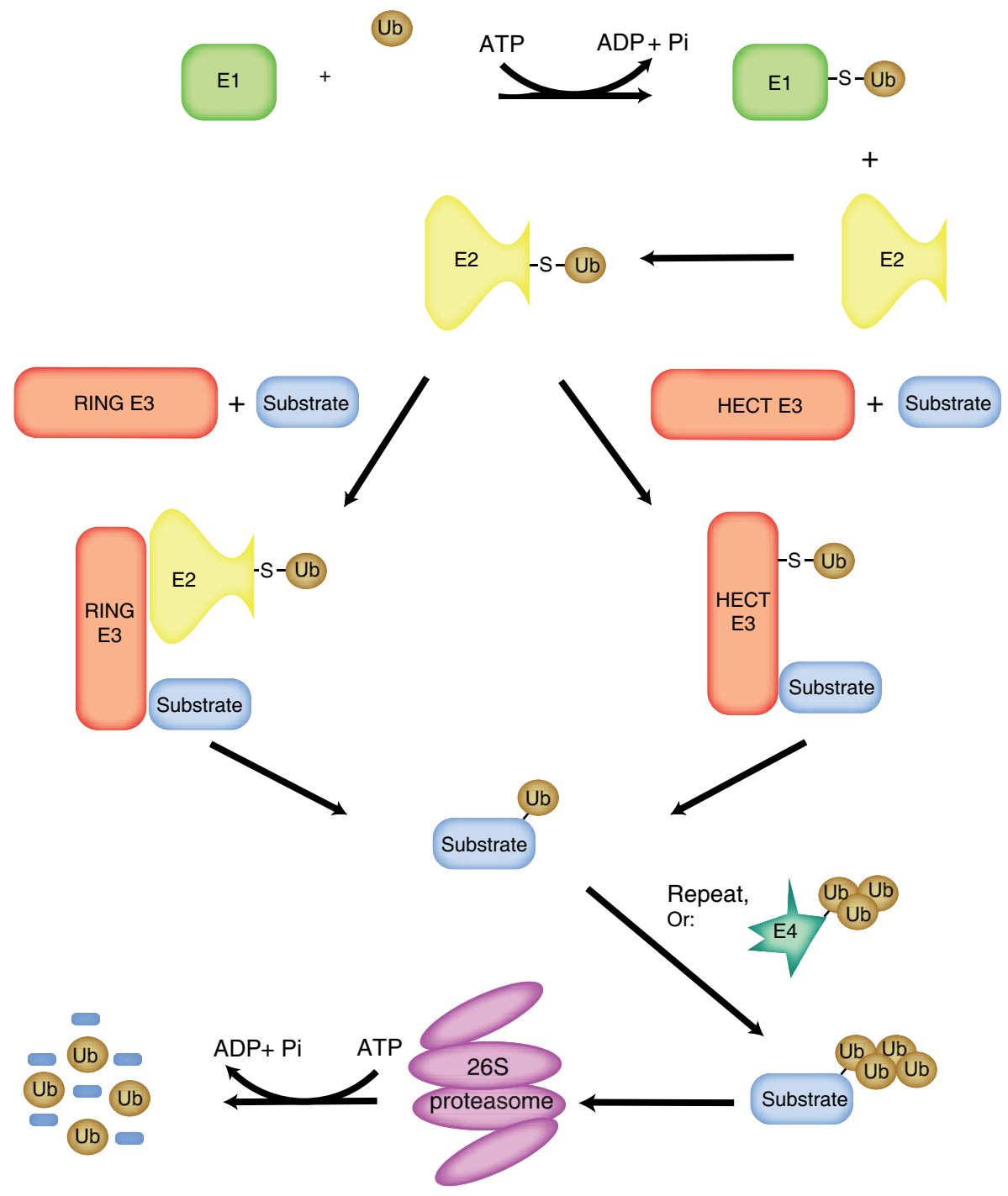


is triggered only following phosphorylation at multiple sites (Ye et al., 2004). Binding partners increase or inhibit the activity of SCF complexes and in particular binding or covalent modification of the C-terminal winged helix bundle domain of the Cullin subunit plays an important role in regulating SCF activity (Duda et al., 2008; Liu et al., 2002). Versatility in substrate specificity for the SCF E3 ligases is provided by the recognition subunit F-box proteins, which bind distinct substrates. Structural analysis of SCF complexes and their cognate substrates is beginning to reveal a wide range of mechanisms for substrate recognition. For example, the atypical F-box protein Fbx4 contains a GTPase domain which is crucial for the binding of a globular domain of its TRF1 substrate (Zeng et al., 2010). By contrast, the Arabidopsis F-box protein TIR1 requires only the presence of the plant hormone auxin in order to bind to its cognate substrates, the Aux/ IAA proteins (Kepinski and Leyser, 2004). Structural studies have revealed that TIR1 is itself the sensor of auxin and that the binding of auxin to TIR1 is necessary to complete the docking site for Aux/ IAA proteins (Tan et al., 2007). Thus, although the F-box motif provides a consistent recognition motif for binding to the SCF scaffold, the mechanism of substrate recognition by the F-box protein varies.

A number of F-box proteins have exhibited roles in development through regulation of substrate levels (see Table 1). This review will focus on the role that F-box proteins play in cell fate determination and signaling during embryogenesis and organogenesis. Although many F-box proteins are also involved in the degradation of cell cycle components (Skaar et al., 2009a; Skaar et al., 2009b), this aspect of F-box protein activity has been previously described in detail (reviewed in Ang and Harper, 2004; Skaar and Pagano, 2009) and this role in development will not be considered here.

\section{F-box proteins and signaling: patterning in the early embryo}

Several F-box proteins have key roles in major signaling pathways involved in patterning of the embryo, for instance $\beta$ Transducin Repeat Containing Protein $(\beta-T R C P)$, which plays pleiotropic roles in regulation of cell signaling. Indeed, $\beta-T R C P$ is one of the best studied of this class of E3 ubiquitin ligases because of its multiple important substrates. Xenopus has $2 \mathrm{~F}$ box $\beta$-TRCP genes, $\beta$-TRCP1 and $\beta$-TRCP2 (also known as $F B X W 1$ and $F B X W 11$ respectively). 4 transcripts of $\beta$-TRCP are expressed in Xenopus, which differ in the presence or absence of amino acid sequences at the $\mathrm{N}$ - or C-termini (Ballarino et al., 2004; Ballarino et al., 2002). Similarly, 2 distinct genes exist in humans with multiple isoforms expressed (Fuchs et al., 1999; Suzuki et al., 1999). Recent evidence suggests that different isoforms of $\beta$-TRCP play different roles in development, with differing tissue-specific expression in mouse, while assays in Xenopus demonstrate differential isoform activity (Seo et al., 2009).

$\beta$-TRCP recognises substrates via binding to seven WD40 repeats present in its $\mathrm{C}$-terminus and phosphorylation of substrates is a prerequisite for binding (for example, Winston et al., 1999). Most $\beta$-TRCP substrates identified to date have a specific phosphodegron (DpSG $\phi$ XpS, where $\phi$ is a hydrophobic amino acid, and $p$ denotes phosphorylation), a motif which, when phosphorylated, allows targeting of the substrate for degradation (reviewed in Ang and Wade Harper, 2005; Jin et al., 2003; Winston et al., 1999). In addition, lysines that are 9-13 amino acids $\mathrm{N}$-terminal to this phosphodegron are preferentially ubiquitylated. This is due to structural constraints associated with optimal presentation of the substrate to the E2 enzyme (Wu et al.,

TABLE 1

\section{SUMMARY OF F BOX PROTEINS INVOLVED IN CELL FATE DETERMINATION}

\begin{tabular}{|c|c|c|c|c|}
\hline Tissue/cell type & F-box component & Substrate & Function & Ref \\
\hline Extraembryonic & Fbw2 & GCM1 & GCM1 required for development of extraembryonic tissue in mammals & Schreiber et al., 2000 \\
\hline \multirow[t]{4}{*}{ Early embryo } & \multirow[t]{3}{*}{$\beta$-TRCP } & $\beta$-Catenin & Regulation of $\beta$-Catenin stability and transcriptional activity & $\begin{array}{l}\text { Latres et al., 1999; Kitagawa et al., 1999; } \\
\text { Hart et al., } 1999\end{array}$ \\
\hline & & Cactus & Regulation of Dorsal transcriptional activity and dorsal-ventral patterning in Drosophila & $\begin{array}{l}\text { Belvin et al., 1995; } \\
\text { Maniatis, } 1999\end{array}$ \\
\hline & & $\mathrm{Ci}$ & Regulation of Ci transcriptional activity & $\begin{array}{l}\text { Jia et al., 2005; } \\
\text { Wang and Li, } 2006\end{array}$ \\
\hline & Fbw7 & Notch & Phosphorylation-dependent degradation of Notch-ICD and regulation of transcription & $\begin{array}{l}\text { Gupta-Rossi et al., 2001; } \\
\text { Wu et al., } 2001\end{array}$ \\
\hline \multirow[t]{3}{*}{ Epithelia } & \multirow[t]{3}{*}{$\beta$-TRCP } & $\mathrm{hDLG}$ & $\begin{array}{l}\text { Dlg inhibits epithelial differentiation in Drosophila, interaction with } \beta \text {-TRCP seen only with hDLG so } \\
\text { far }\end{array}$ & $\begin{array}{l}\text { Mantovani and Banks, 2003; } \\
\text { Woods et al., } 1996\end{array}$ \\
\hline & & IאB & $\mathrm{NF}-\mathrm{kB}$ signalling implicated in proliferation and differentiation of basal layer of epidermis & $\begin{array}{l}\text { Hu et al., 1999, } \\
\text { Takeda et al., } 1999\end{array}$ \\
\hline & & TAp63 $\gamma$ & Possible role in epidermal differentiation via regulation of transcriptional activity & Gallegos et al., 2008 \\
\hline \multirow[t]{2}{*}{ Haematopoietic } & \multirow[t]{2}{*}{ Fbw7 } & c-Myc & $\begin{array}{l}\text { Abnormal thymocyte development due to aberrant c-myc regulation; regulates haematopoietic stem } \\
\text { cell gene expression signature }\end{array}$ & $\begin{array}{l}\text { Onoyama et al., } 2007 \text {, } \\
\text { Reavie et al., } 2010\end{array}$ \\
\hline & & Notch & Negative regulation of Notch signalling in haematopoietic, vascular and cardiac development in mice & Tetzlaff et al., 2004 \\
\hline \multirow[t]{2}{*}{ Muscle } & \multirow[t]{2}{*}{ MAFbx } & MyoD & Promotes MyoD polyubiquitylation and degradation in vitro and in vivo & $\begin{array}{l}\text { Lagirand-Cantaloube et al., 2009, } \\
\text { Tintignac et al., } 2005\end{array}$ \\
\hline & & myogenin & Promotes myogenin polyubiquitylation and degradation & Jogo et al., 2009 \\
\hline \multirow[t]{3}{*}{ Neural } & $\beta$-TRCP & REST & Degradation of transcriptional repressor, promoting neuronal differentiation & $\begin{array}{l}\text { Chong et al., 1995, } \\
\text { Westbrook et al., } 2008\end{array}$ \\
\hline & Fbw2 & $\mathrm{gcm}$ & Degradation of $\mathrm{gcm}$ allows cell cycle exit and differentiation of glial progenitors in Drosophila & $\begin{array}{l}\text { Ho et al., 2009, } \\
\text { Hosoya et al., } 1995\end{array}$ \\
\hline & Skp2 & Xic1 & Regulation of primary neuronal differentiation in Xenopus & Boix-Perales et al., 2007 \\
\hline \multirow[t]{2}{*}{ Neural crest } & Ppa & Slug & Regulation of Slug stability during neural crest development & Vernon et al., 2006 \\
\hline & Fbw7 & Unknown & Fbw7 necessary for development of neural crest & Almeida et al., 2010 \\
\hline
\end{tabular}


2003). The phosphodegron is a highly efficient binding motif that can act as a transferable destruction signal (Wulczyn et al., 1998).

A role for $\beta$-TRCP was first identified from studies with the Drosophila orthologue, Slimb (Jiang and Struhl, 1998). Loss of function of Slimb resulted in the accumulation of the transcription factors Armadillo/ $\beta$-catenin (Arm) and Cubitus interruptus $(\mathrm{Cl})$, components of the Wnt and Hedgehog $(H h)$ signaling pathways, respectively. It was proposed that Slimb negatively regulates these pathways through proteolysis of Arm and Ci. Since then, $\mathrm{SCF}^{\beta-}$ TRCP complexes have been demonstrated to degrade a large number of substrates, many of which have roles during development (reviewed in Fuchs et al., 2004).

\section{Wnt signaling}

The transcription factor $\beta$-catenin mediates signaling via the canonical Wnt pathway, which regulates multiple developmental processes, for instance dorsal-ventral axis formation in Xenopus. $\beta$-catenin has an asymmetric localisation in the early Xenopus embryo, concentrated on the future dorsal side of the embryo, allowing the expression of dorsal-specific genes. Elevations in dorsal $\beta$ catenin levels are attributed to activation of Wntsignaling (Larabell et al., 1997); $\beta$-catenin is degraded by Ub-mediated proteolysis, and removal of glycogen synthase kinase $3 \beta$ (GSK3 $\beta$ ) phosphorylation sites or activation of Wnt signaling stabilises the protein (Aberle et al., 1997). This has led to a model whereby, in the absence of Wnt signaling, $\beta$-catenin is degraded in a manner dependent upon phosphorylation at GSK3 $\beta$ sites (Fig. 2), but in response to Wnt signaling, $\beta$-catenin is stabilised and can promote gene expression. $\beta$-TRCP has been characterised as a negative regulator of $W n t$ signaling; overexpression of $\beta$-TRCP reduces formation of Wnt8-induced secondary axes in Xenopus, and inhibition of SCF ${ }^{\beta-T R C P}$ using a dominant negative $F$-box deleted ( $\Delta \mathrm{F}$-box) mutant results in formation of secondary axes (Lagna et al., 1999; Marikawa and Elinson, 1998). The latter effect is inhibited by cooverexpression of mediators of the Wnt pathway (Marikawa and Elinson, 1998). Subsequently, SCF ${ }^{\beta-T R C P}$ was demonstrated to be the E3 ligase for $\beta$-catenin (Fuchs et al., 1999; Hart et al., 1999; Latres et al., 1999).

A distinct role has been identified for SCF ${ }^{\beta-T R C P}$ in neural crest formation. Neural crest (NC) development depends on the activity of the Snail family of transcription factors, which trigger the epithelial to mesenchymal transition, via repression of $E$-cadherin that results in the migration of NC cells from the neural tube throughout the embryo. Work in several cell lines has demonstrated that Wnt signaling leads to stabilisation of Snail through

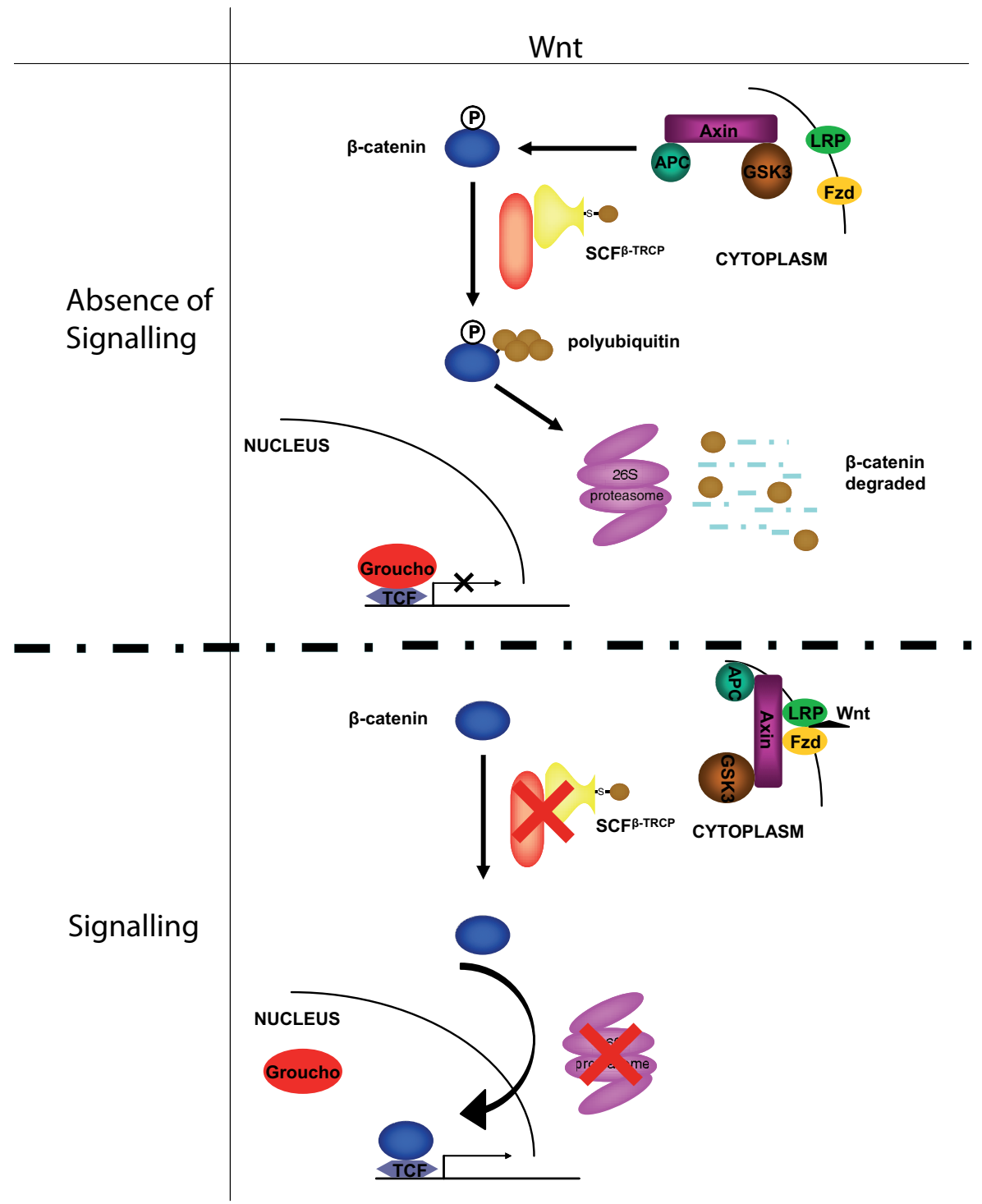

Fig. 2. Regulation of Wnt signaling by Ub mediated protein degradation. The Wnt pathway is shown in the presence and absence of Wnt, leading to activation and inhibition, respectively, of $\beta$-catenin transcriptional activity. In the absence of Wnt, $\beta$-catenin is phosphorylated by GSK3 and targeted for degradation by SCF ${ }^{\beta-T R C P}$. When Wnt is present, binding by the Fzd receptor phosphorylate $\beta$-catenin. $\beta$-catenin is therefore not degraded and enters the nucleus to form a polyposis coli; Fzd, frizzled; GSK3, glycogen synthase kinase 3; LRP, low density lipoprotein receptor related protein; TCF, T cell factor. $P$ is used to denote phosphorylation.

inhibition of SCF ${ }^{\beta-T R C P}$ mediated degradation. GSK3 $\beta$ targets human Snail for phosphorylation at serines between amino acids 92-120 and this is required for nuclear export, $\beta$-TRCP binding and proteasomal degradation (Yook et al., 2005; Zhou et al., 2004).

\section{Hh signaling}

The Hh signaling pathway is involved in a range of patterning processes during development, many of which have been identified using Drosophila as a model system (reviewed in Ingham and McMahon, 2001; Ingham and Placzek, 2006). In the absence of signaling, a G-protein coupled receptor, Smoothened (Smo), is 
inhibited by a multipass transmembrane receptor for $\mathrm{Hh}$, Patched (Ptc). Binding of secreted $\mathrm{Hh}$ proteins to Ptc alleviates inhibition of Smo and results in the activation of signaling within the cell. The transcription factor $\mathrm{Ci}$ (the Gli family in mammals) is the major mediator of $H h$ signaling in cells. In the absence of $H h$ signaling, Ciis a transcriptional repressor for genes such as Decapentaplegic (dpp). However, when Hh signaling is activated, dpp expression is de-repressed. The duality of $\mathrm{Ci}$ activity is achieved by proteolytic processing; full length $\mathrm{Ci}(\mathrm{Ci155})$ is a transcriptional activator and a C-terminally truncated form (Ci75) is a repressor. It appears that processing of $\mathrm{Ci}$ to repressor forms is mediated by the SCFSlimb complex, the Drosophila homologue of SCF ${ }^{\beta-T R C P}$. Recruitment of SCFSlimb to $\mathrm{Ci}$ requires phosphorylation of $\mathrm{Ci}$ protein at multiple residues in the $\mathrm{C}$-terminus by Protein Kinase $\mathrm{A}$ (PKA) and GSK3. This facilitates further phosphorylation by Casein Kinase I A and E, followed by SCFSlimb recruitment (Jia et al., 2005; Smelkinson et al., 2007). SCF ${ }^{\text {Slimb-mediated process- }}$ ing of $\mathrm{Ci}$ is unusual, as ubiquitylation triggers partial proteolysis rather than full destruction (Fig. 3). SCFSlimb activity must be inhibited following $H$ pathway activation; this allows accumulation of the $\mathrm{Ci}$ activator form (Ci155) rather than its repressor form (Ci75). The situation in mammals is more complex. There are 3 Gli proteins, homologues of $\mathrm{Ci}$, Gli1, Gli2 and Gli3. Mouse Gli3 is efficiently processed to a repressive form (Pan et al., 2006), most likely by SCF ${ }^{\text {-TRCP }}$ (Wang and Li, 2006), whilst Gli2 is important for transcriptional activation. In mouse, Gli2 is inefficiently processed to the repressive form and instead can be degraded fully by the SCF ${ }^{\beta-T R C P}$ complex (Bhatia et al., 2006; Pan et al., 2006).

\section{$N F-\kappa B$ signaling}

Nuclear factor- $\kappa B(N F-\kappa B)$ was first identified as a transcription factor involved in expression of the immunoglobulin $\kappa$ light chain gene in B cells (Sen and Baltimore,

Fig. 3. Regulation of Hh signaling by Ub mediated protein processing. The Hh pathway is shown in the presence and absence of Hh, leading to activation and inhibition, respectively, of $\mathrm{Ci}$ transcriptional activity. In the absence of $\mathrm{Hh}, \mathrm{Ci}$ is phosphorylated by PKA, active in the presence of inhibited Smo, and polyubiquitylated by $S_{C F}{ }^{-}$ TRCP. This targets Ci for partial proteolysis by the 265 proteasome, leading to the formation of a transcriptional repressorform. When Hh is present, the binding of Hh to Ptc alleviates repression of Smo and inhibits activation of PKA and phosphorylation of $\mathrm{Ci}$. Ci therefore enters the nucleus in a transcriptionally active form that has not been proteolysed. Note the similarities between the Wnt and Hh pathways: signaling at the external surface of the membrane inhibits intracellular signaling and phosphorylation of a transcription factor, which in turn inhibits targeting by SCF-TRCP to the $26 \mathrm{~S}$ proteasome. Ci, Cubitus interruptus (Act and Rep are used to denote activator and repressor forms, respectively); dpp, decapentaplegic; Hh, Hedgehog; PKA, protein kinase A; Ptc, Patched; Smo, Smoothened. P is used to denote phosphorylation.
1986). It is a member of the Re/ family of transcription factors, of which there are three genes in Drosophila: Dorsal, Dif and Relish (Dushay et al., 1996; Ip et al., 1993; Steward, 1987). Also important in mounting an effective immune response, the developmental role played by $N F-\kappa B$ was elucidated through genetic analysis of signaling by its Drosophila homologue, Dorsal (reviewed in Karin and Ben-Neriah, 2000). Ablation of Dorsalactivity resulted in embryos lacking ventral structures, which require nuclear localisation of Dorsal at the ventral side of the embryo. Dorsal is usually bound in the cytoplasm by its inhibitor, Cactus, a homologue of mammalian IKB (Geisler et al., 1992), such that its nuclear localisation signal is obscured and entry to the nucleus does not occur (Henkel et al., 1992; Wu and Anderson, 1998). Ventral activation of the IL-1 receptorhomologue, Toll(Hashimoto et al., 1988), leads to phosphorylation and degradation of Cactus, allowing Dorsal to dimerise and enter the nucleus as an active complex (Belvin et al., 1995).

The SCF complex responsible for targeting $I \kappa B$ for degradation is, once again, SCF ${ }^{\beta-T R C P}$, which ubiquitylates $I \kappa B$ at lysines 21 and 22 (Maniatis, 1999) after modification of $I \kappa B$ by phosphoryla-

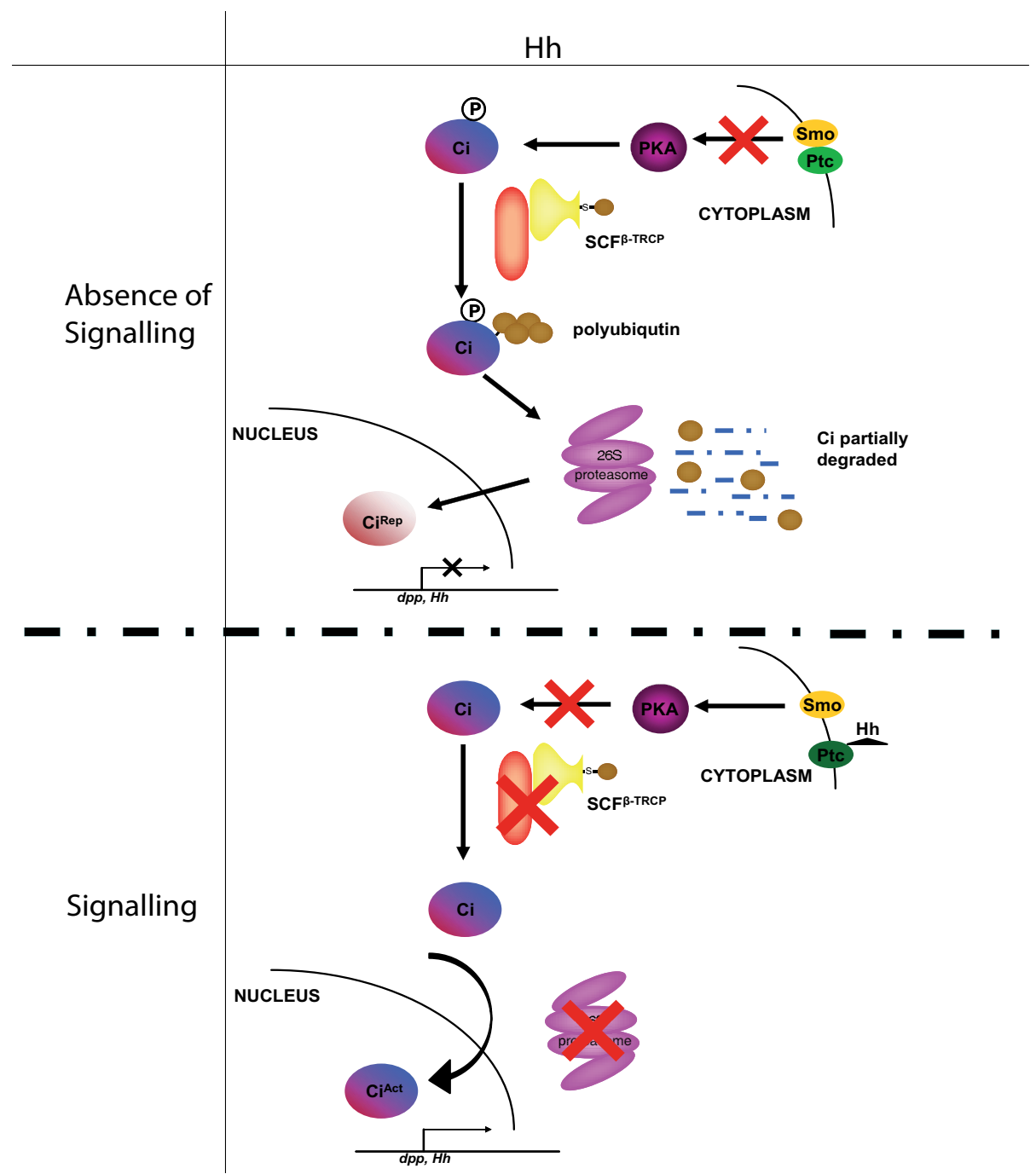


tion (Alkalay et al., 1995). Inhibition of the $26 \mathrm{~S}$ proteasome also inhibits $N F-\kappa B$ signaling, suggesting that the post-translational modifications that occur to $I_{\kappa} B$ are insufficient to cause dissociation from $N F-\kappa B$ (Lin et al., 1995). Intriguingly, a role for $N F-\kappa B$ signaling in dorsal-ventral patterning in vertebrates has not been established and $N F-\kappa B 1$-null mice do not display any gross developmental abnormalities (reviewed in Attar et al., 1997). However, $N F-\kappa B$ signaling does seem to play a role in the formation of the epidermis, as knockout of a kinase responsible for phosphorylation of $I \kappa B$, I $\kappa B$ kinase $\alpha(I K K \alpha)$, leads to severe deformity and death of neonates 4 hours post-partum due to thickening of the epidermis (see below).

The examples given above highlight several common features of signaling regulated by SCF ${ }^{\beta-T R C P}$. Most notably, they illustrate how the UPS can produce a rapid response to signaling events. For instance, in the absence of Wnt signaling, $\beta$-catenin is degraded by SCF ${ }^{\beta-T R C P}$, while activation of $W n t$ signaling rapidly stabilises the protein through inhibition of GSK3 $\beta$. This allows a much faster response than if $\beta$-catenin needed to be synthesised de novo. Similarly, the response allowed by the switching of $\mathrm{Ci}$ from a repressor to an activator form, following inhibition of SCFSlimb by $\mathrm{Hh}$ signaling, is more rapid than that allowed by changes in expression of repressor and activator genes. It is also noteworthy that, in all these cases, signaling begins with kinases and, for instance, targeting of the substrate to SCF ${ }^{\beta-T R C P}$ is mediated by phosphorylation of a phosphodegron motif. Integration of the UPS and phosphorylation cascades allows a finetuning of the system by combining reversible and irreversible aspects of regulation.

\section{$\boldsymbol{\beta}$-TRCP and epidermal development}

The epidermis consists of a stratified epithelium that is made up of keratinocytes. Mitotically active keratinocytes reside in the inner basal layer and continuously renew the surface of the epidermis by detaching from the basement membrane and migrating to the outer, terminally differentiated, layer. The transcription factor p63, a member of the p53 family, is crucial for the differentiation of keratinocytes and $p 63$-null mice lack epidermis, epidermal structures and squamous epithelia (Mills et al., 1999; Yang et al., 1999). The gross manifestation of the lack of epidermis is the truncation of the limbs and severe craniofacial abnormalities.

There are 6 isoforms of $p 63$ resulting from differential promoter usage, producing the full $\mathrm{N}$-terminal TAp63 and the N-terminally truncated $\Delta \mathrm{Np} 63$, and alternative splicing at the 3 ' end of the transcripts, to produce the $\alpha, \beta$ and $\gamma$ isoforms of both TAp63 and $\Delta$ Np63. Both TAp63 and $\Delta$ Np63 are transcriptionally active, although only TAp63 contains the transactivation domain (reviewed in Candi et al., 2008). In mature epidermis, $\Delta N p 63 \alpha$ appears to be the major isoform expressed in proliferating keratinocytes in the basal layer, but not present in suprabasal layers, although several isoforms are claimed to be required for normal stratification in the embryo (Gu et al., 2006; Koster and Roop, 2004). It has been reported that there is an interaction between endogenous SCF ${ }^{\beta-T R C P}$ and TAp63 $\gamma$ in a human keratinocyte cell line, HaCaT (Gallegos et al., 2008). Unexpectedly, the interaction with SCF ${ }^{\beta-T R C P}$ increases the half life of p63 and ubiquitylation of TAp63 $\gamma$ appears to increase its transcriptional activity by around $50 \%$, as assessed by RT-PCR. Although it is likely that $\mathrm{SCF}^{\beta-T R C P}$ has a role in epidermal development in vivo there are, as yet, no data to confirm this.

In contrast to its role in promoting the stability and activity of p63, SCF ${ }^{\beta-T R C P}$ also interacts with $h D L G$, the human homologue of Drosophila discs large $(D / g)$. Mutations in $D / g$ result in invasive growth of epithelial cells in Drosophila (Woods et al., 1996) and $h D L G$ is recruited to the plasma membrane by E-cadherin cell-cell adhesion, where it organises junction structures and the actin cytoskeleton (Ide et al., 1999; Reuver and Garner, 1998). Interaction with SCF ${ }^{\beta-T R C P}$ promotes the ubiquitylation and degradation of hDLG (Mantovani and Banks, 2003). The interaction appears to be promoted by phosphorylation of the SH3 domain of hDLG (Mantovani et al., 2001), although the physiological relevance of this interaction remains unclear.

As well as the central role played by $p 63$ in epidermal formation and stratification, it appears that $N F-\kappa B$ signaling may also play a role in the differentiation of epidermal cells. The inhibitory binding partner of $N F-\kappa B, I \kappa B$, is targeted for degradation following phosphorylation by $I K K$, (reviewed in Karin and Ben-Neriah, 2000). The $I K K \alpha$-null mouse appears to phenocopy the p63-null mouse, as at a superficial level the neonates lack limbs and show aberrant craniofacial development (Hu et al., 1999; Takeda et al., 1999). Closer inspection of the $I K K \alpha$ mutants shows that skeletal organisation is approximately wild type, but the epidermis is 5- to 10-fold thicker and so limbs cannot emerge out of the thickened skin. The epidermis is composed of a single layer and it would appear that the loss of $N F-\kappa B$ signaling leads to gross overproliferation of the basal layer.

Intriguingly, in Drosophila one of the target genes of Dorsal is twist, ablation of which is associated with craniofacial abnormalities (Howard et al., 1997). Further, IKK $\alpha$ is a direct and indirect target of TAp63, both by direct binding to a p53-like consensus sequence on the $I K K \alpha$ promoter and by upregulation of the transactivators Ets-1 and GATA-3 (Candi et al., 2006; Gu et al., 2004; Sil et al., 2004). IKK interacts with $\Delta$ Np63 $\alpha$ and promotes its Ub mediated degradation (Chatterjee et al., 2010), suggesting that $N F-\kappa B$ and $p 63$ share multiple components which regulate their activities, the most prominent being the $\mathrm{SCF}^{\beta-T R C P} \mathrm{E} 3$ ligase. However, the exact level of crosstalk between these two transcription factors remains to be firmly established.

\section{Other developmental signaling pathways}

$\mathrm{SCF}^{\beta-T R C P}$ is not the only SCF complex to play a role in major signaling pathways. Mammalian $F B W 7$ was initially identified as an F-box protein in a yeast screen for effectors of the cell cycle and termed cdc4 (Nurse et al., 1976). The Caenorhabditis elegans homologue, SEL-10, was found through mutational analysis to be responsible for the degradation of the Notch intracellular domain, the effector of Notch signaling, and thus termination of the Notch signal (Gupta-Rossi et al., 2001; Wu et al., 2001). In C. elegans, mutation of SEL-10 resulted in aberrant vulval development, a process dependent upon Notch signaling (Hubbard et al., 1997). In mice, knockout of $F B W 7$ results in embryonic lethality at E10.5 through a combination of aberrant haematopoietic and vascular development and heart maturation defects (Tetzlaff et al., 2004). Defects in neural tube closure and development of all brain regions were also observed at E9.5. Intriguingly $\mathrm{FBW} 7^{+/-}$mice appear grossly phenotypically normal up to 1 year of age and, despite reports of mutation of FBW7 in T-ALL cell lines and 
patient samples (O'Neil et al., 2007), did not display an increased incidence of tumorigenesis (Tetzlaff et al., 2004).

However, a role for FBW7 as a tumour suppressor has been observed in the absence of p53 activity (Mao et al., 2004). Most recently, conditional inactivation of $F B W 7$ in murine $T$ cells was found to increase the number of double-positive thymocytes but not single-positive thymocytes, due to increased apoptosis of double-positive thymocytes (Onoyama et al., 2007). This is suggestive of a developmental block in thymocyte maturation and is supported by an increased incidence of thymic lymphoma in LckCre/FBW $7^{F / F}$ mice resulting from clonal expansion of progenitors bearing an immature, double-positive phenotype. These abnormalities in thymocyte development were also observed in CD4Cre/FBW7 F/ F/RBP-JF/ $F$ mice but not in CD4-Cre/FBW7F/ F/C$M y c^{F / F}$ mice, leading the authors to conclude that abnormal thymocyte development arises due to disregulation of $c-M y c$ and not Notch signaling (Onoyama et al., 2007). More recently, FBW7 has been found to play a more general role in haematopoiesis, as regulation of the level of c-Myc was found to be sufficient to direct the gene expression signature of haematopoietic stem cells. Intriguingly, adult and embryonic haematopoietic stem cells displayed different responses to c-Myc levels at the level of gene expression (Reavie et al., 2010).

\section{Skp2, $\beta$-TRCP, FBW2 and neural differentiation}

SCFSkp2 is an SCF complex containing the leucine rich repeat F-box protein Skp2 (also known as FBXL1). SCFSkp2 has been shown to ubiquitinate a number of cell cycle substrates, including c-Myc (Kim et al., 2003; von der Lehr et al., 2003), Cyclin E (Nakayama et al., 2000), the cyclin dependent kinase inhibitors (CKI) p27 Kip1 (Carrano et al., 1999), p57 Kip2 (Kamura et al., 2003) and the Xenopus CKI Xic1 (Lin et al., 2006), and has been implicated in development of many cancers (Bashir et al., 2004; Kitagawa et al., 2008; Signoretti et al., 2002). However, in addition to a central role in proteolysis of cell cycle regulators, SCFSkp2 may have additional functions in differentiation and development.

Recent work has highlighted a role for Skp2 during neural development in Xenopus. Primary neurogenesis in this species results in differentiation of neurons that mediate the early movements of the embryo. This process is driven by a cascade of proneural basic Helix-Loop-Helix (bHLH) transcription factors, resulting in the expression of markers of terminal neuronal differentiation, such as neural $\beta$-tubulin ( $N \beta T$ ) (reviewed in Lee, 1997). Depletion of Skp2 protein using translation-blocking anti-sense morpholinos promotes primary neurogenesis, as assessed by expression of $N \beta T$, by a mechanism independent of changes in the cell cycle. Conversely, overexpression of Skp2 inhibits formation of primary neurons and this inhibition occurs at an early point in the bHLH cascade (Boix-Perales et al., 2007). Skp2-mediated inhibition of this process is likely to occur via ubiquitylation of substrates by the SCFSkp2 complex, as overexpression of a $\Delta \mathrm{F}$ box form of Skp2, which can no longer bind to Skp1 and therefore the rest of the SCF complex, has no effect on formation of primary neurons (Boix-Perales et al., 2007). As the CKI Xic1 is required for differentiation of primary neurons in Xenopus (Vernon et al., 2003), degradation of Xic1 in neural precursors may be the major mechanism by which SCFSkp2 regulates this process. It is interesting to note in this regard that the $\mathrm{CKI}$ p $57^{\mathrm{Kip} 2}$ has been reported to associate with several proteins involved in differentiation, such as MyoD (reviewed in Besson et al., 2008; Reynaud et al., 2000). However, unlike the degradation of the CKI p2 $7^{\text {Kip1 }}$ by SCFSkp2 in mammals, Xic1 degradation in Xenopus by SCF'sk2 does not require prior phosphorylation of its CKI target (Lin et al., 2006).

The stability of Skp2 itself is regulated by the UPS in mammals, and the E3 ligase responsible is the APC/C coupled to the substrate recognition subunit, Cdh1 (Bashir et al., 2004; Wei et al., 2004). Degradation of Skp2 by APC/C ${ }^{\mathrm{Cdh} 1}$ is also important for myogenesis, as depletion of Cdh1 by siRNA in the mouse skeletal muscle cell line, $\mathrm{C} 2 \mathrm{C} 12$, reduces cellular elongation and myogenic fusion (Li et al., 2007). It was found that the attachment of $\mathrm{Ub}$ to and degradation of Skp2 was greatly reduced in Cdh1depleted cells when compared to control C2C12 cells. The authors speculated that the increase in Skp2 levels in Cdh1depleted cells would lead to reduced levels of p21 and p27, cell cycle regulators which are crucial for muscle differentiation (Vernon and Philpott, 2003; Zhang et al., 1999). However, it was also suggested that the myogenic transcription factor myf5 is a target for APC/C ${ }^{\text {Cdh1 }}$ (Li et al., 2007).

Although a key determinant in neural differentiation, SCFSkp2 is not the only E3 ligase to have been implicated in this process. Recently it has been shown that the master repressor of neuronal gene expression, RE1 silencing transcription factor (REST), is a substrate for SCF ${ }^{\beta-T R C P}$-mediated degradation (Chong et al., 1995; Schoenherr and Anderson, 1995; Westbrook et al., 2008). However, the functional relevance of this interaction to neural development is not clear, as the in vivo data presented are mostly obtained from epithelial cells or cell lines of non-neural origin. Nevertheless, data from neural stem and progenitor cells seem to suggest that endogenous REST stability is regulated by $\mathrm{SCF}^{\beta-\mathrm{TRCP}}$ during early neural differentiation (Westbrook et al., 2008).

FBW2, another F-box protein, currently has only one known substrate, glial cells missing homologue 1 (GCM1), an interaction observed in a placental cell line (Chiang et al., 2008). In Drosophila, glial cells missing $(\mathrm{gcm})$ was first identified as a glial fate switch gene which, when overexpressed, caused an increase in the number of glial cells but not total number of cells in the nervous system (Hosoya et al., 1995; Jones et al., 1995). More recent work suggests that $\mathrm{gcm}$ degradation allows cell cycle exit and differentiation of glial progenitors in Drosophila (Ho et al., 2009). Rapid degradation of $\mathrm{gcm}$ allows the daughter cells of the thoracic neuroglioblast, NB6-4T, which expresses $\mathrm{gcm}$ at low levels, to adopt differing cell fates following asymmetric segregation of $\mathrm{gcm}$ transcript. Recently, a role for $\mathrm{gcm}$ in the differentiation of the Drosophila haemocyte lineage has also been reported (Jacques et al., 2009). Intriguingly, although the mammalian homologues GCM1 and GCM2 share high sequence homology in the DNA binding domain and conservation of domain structure (Akiyama et al., 1996; Altshuller et al., 1996; Kim et al., 1998), there appears to be no functional conservation between Drosophila and mammals (Basyuk et al., 1999; Kanemura et al., 1999).

GCM1 is mainly expressed in the placenta, with lower levels of expression in the thymus, whilst GCM2 is expressed in the developing mouse parathyroid gland (Basyuk et al., 1999; Kim et al., 1998). In the placenta, GCM1 is absolutely required for expression of the fusogenic protein syncytin and knockout leads to embryonic lethality at E9.5-10 due to aberrant labyrinth forma- 
tion (Anson-Cartwright et al., 2000; Schreiber et al., 2000). In contrast to the extraembryonic tissue, there appear to be no embryonic abnormalities associated with GCM1 knockout. Although little is known about the role of degradation in the regulation of GCM1, it is noteworthy that both Drosophila and mammalian homologues have a conserved role for the UPS despite a complete lack of conservation of developmental function.

\section{Ppa, Fbw7 and neural crest development}

The transcription factor Slug is required for NC development in Xenopus (for example, LaBonne and Bronner-Fraser, 2000), and the degradation of Slug by the F-box protein Partner of Paired (Ppa, also known as FBXL14 in vertebrates) has been reported in Xenopus (Vernon and LaBonne, 2006). Using overexpression and knock-down techniques, it was demonstrated that SCFPpa mediated degradation of Slug was important for patterning the neural plate border; overexpression of Ppa expanded the neural plate, at the expense of the NC, whereas by contrast, overexpression of a Ppa-refractory Slug mutant expanded the NC and led to premature migration of NC cells in the spinal cord. It is interesting to note that two key regulators of NC development, Slug and Snail, are degraded by SCF E3 ligases (SCFPpa and SCF $^{\beta-T R C P}$ respectively, see above).

A further role for F-box proteins in the development of the NC has been recently described in Xenopus, where the function of Fbw7 was perturbed by expression of an Fbw7 7 F-box mutant (Almeida et al., 2010). Loss of Fbw7 activity led to reduced expression of both Slug and Snail, as well as $c-M y c$, and the loss of NC-derived tissues, such as melanocytes. The activity of Fbw7 appeared to be required specifically for development of NC, as expression of early markers in other tissues was unperturbed when Fbw7 activity was inhibited. Thus it appears that several stages of NC development are regulated by SCF complexes.

\section{MAFbx and myogenesis}

Muscle Atrophy F-box (MAFbx), also known as Atrogin-1 and $F B X 032$, was first identified as an E3 ligase that could target MyoD, the master regulator of myogenesis, for Ub-mediated proteolysis (Davis et al., 1987; Lassar et al., 1991) and is a muscle-specific gene upregulated during muscle atrophy (Bodine et al., 2001; Gomes et al., 2001). In C2C12 cells, MAFbx expression increased during ex vivo differentiation (Tintignac et al., 2005).

MAFbx was first characterised following a yeast two-hybrid screen using Skp1 binding proteins as prey and MyoD as bait (Tintignac et al., 2005), establishing that the two proteins interacted via an LXXLL motif on MyoD. This suggests that, unusually for an F-box protein, MAFbx recognises MyoD independently of MyoD phosphorylation state. Overexpression of $M A F b x$ reduced the half-life of MyoD and also increased the ubiquitylation of MyoD. Conversely, inhibition of MAFbx using a dominant negative $\Delta \mathrm{F}$-box construct $(M A F b x \Delta F)$ increased the half-life of MyoD. As well as the considerable evidence for MyoD degradation by MAFbx in vitro, a recent report has also demonstrated increased polyubiquitylation of MyoD following transfection of MAFbx, but not MAFbx $\Delta F$, into $\mathrm{C} 2 \mathrm{C} 12$ cells (Lagirand-Cantaloube et al., 2009). A direct interaction between SCFMAFbx and myogenin, a
bHLH transcription factor downstream of MyoD, has been demonstrated and SCFMAFbx was seen to promote polyubiquitylation and degradation of myogenin in vivo (Jogo et al., 2009).

\section{Conclusions}

The UPS is well known for its housekeeping role in protein turnover but it is becoming increasingly clear that it also plays a crucial role in dynamic processes involved in development, where ubiquitylation can result in either protein destruction, proteolytic processing or change in sub-cellular localization. Single SCF E3 ligase complexes may have multiple targets, exemplified by $\mathrm{SCF}^{\beta-T R C P}$, which potentially results in co-ordination of developmental signaling pathways, while single targets can be ubiquitylated by more than one E3 ligase complex. The selectivity, irreversibility and responsiveness of SCF complexes make them excellent candidates for developmental regulation, while substrate ubiquitylation is also often regulated by further post-translational substrate modification such as phosphorylation, which can finetune cellular responses.

Such complexity, illustrated well by the multiple roles of $\mathrm{SCF}^{\beta-T R C P}$, often makes it difficult to define the role of individual E3 ligases in distinct developmental events. However, the use of multiple model systems and analysis of individual substrates can both facilitate this reductionist approach to identifying the role of distinct SCF complexes, and allow us to explore the role of multiple ubiquitylation pathways in regulating complex developmental events. There is clearly a lot to learn.

\section{Acknowledgements}

GSM was funded by a Medical Research Council studentship, CJH by a Cancer Research UK studentship and HW was funded by a Wellcome Trust studentship. Work in AP's lab is funded by MRC Research Grant G0700758

\section{References}

ABERLE, H., BAUER, A., STAPPERT, J., KISPERT, A. and KEMLER, R. (1997). beta-catenin is a target for the ubiquitin-proteasome pathway. EMBO J 16: 3797-3804.

AKIYAMA, Y., HOSOYA, T., POOLE, A.M. and HOTTA, Y. (1996). The gcm-motif: a novel DNA-binding motif conserved in Drosophila and mammals. Proc Natl Acad Sci USA 93: 14912-14916.

ALKALAY, I., YARON, A., HATZUBAI, A., ORIAN, A., CIECHANOVER, A. and BEN-NERIAH, Y. (1995). Stimulation-dependent I kappa B alpha phosphorylation marks the NF-kappa B inhibitor for degradation via the ubiquitin-proteasome pathway. Proc Natl Acad Sci USA 92: 10599-10603.

ALMEIDA, A., WISE, H., HINDLEY, C., SLEVIN, M., HARTLEY, R. and PHILPOTT, A. (2010). The F-box protein Cdc4/Fbxw7 is a novel regulator of neural crest development in Xenopus laevis. Neural Dev 5: 1.

ALTSHULLER, Y., COPELAND, N.G., GILBERT, D.J., JENKINS, N.A. and FROHMAN, M.A. (1996). Gcm1, a mammalian homolog of Drosophila glial cells missing. FEBS Lett 393: 201-204.

ANG, X.L. and HARPER, J.W. (2004). Interwoven Ubiquitination Oscillators and Control of Cell Cycle Transitions. Sci STKE 2004: pe31.

ANG, X.L. and WADE HARPER, J. (2005). SCF-mediated protein degradation and cell cycle control. Oncogene 24: 2860-2870.

ANSON-CARTWRIGHT, L., DAWSON, K., HOLMYARD, D., FISHER, S.J., LAZZARINI, R.A. and CROSS, J.C. (2000). The glial cells missing-1 protein is essential for branching morphogenesis in the chorioallantoic placenta. Nat Genet 25: 311-314. 
ATTAR, R.M., CAAMANO, J., CARRASCO, D., IOTSOVA, V., ISHIKAWA, H., RYSECK, R.P., WEIH, F. and BRAVO, R. (1997). Genetic approaches to study Rel/NF-kappa B/I kappa B function in mice. Semin Cancer Biol 8: 93-101.

BALLARINO, M., FRUSCALZO, A., MARCHIONI, M. and CARNEVALI, F. (2004). Identification of positive and negative regulatory regions controlling expression of the Xenopus laevis betaTrCP gene. Gene 336: 275-285.

BALLARINO, M., MARCHIONI, M. and CARNEVALI, F. (2002). The Xenopus laevis beta $\mathrm{TrCP}$ gene: genomic organization, alternative splicing, $5^{\prime}$ and $3^{\prime}$ region characterization and comparison of its structure with that of human beta TrCP genes. Biochim Biophys Acta 1577: 81-92.

BASHIR, T., DORRELLO, N.V., AMADOR, V., GUARDAVACCARO, D. and PAGANO, M. (2004). Control of the SCF(Skp2-Cks1) ubiquitin ligase by the APC/C(Cdh1) ubiquitin ligase. Nature 428: 190-193.

BASYUK, E., CROSS, J.C., CORBIN, J., NAKAYAMA, H., HUNTER, P., NAITOUMESMAR, B. and LAZZARINI, R.A. (1999). Murine Gcm1 gene is expressed in a subset of placental trophoblast cells. Dev Dyn 214: 303-311.

BELVIN, M.P., JIN, Y. and ANDERSON, K.V. (1995). Cactus protein degradation mediates Drosophila dorsal-ventral signaling. Genes Dev 9: 783-793.

BESSON, A., DOWDY, S.F. and ROBERTS, J.M. (2008). CDK Inhibitors: Cell Cycle Regulators and Beyond. Dev Cell 14: 159-169.

BHATIA, N., THIYAGARAJAN, S., ELCHEVA, I., SALEEM, M., DLUGOSZ, A., MUKHTAR, $H$. and SPIEGELMAN, V.S. (2006). Gli2 is targeted for ubiquitination and degradation by beta-TrCP ubiquitin ligase. J Biol Chem 281: 19320-19326.

BODINE, S.C., LATRES, E., BAUMHUETER, S., LAI, V.K., NUNEZ, L., CLARKE, B.A., POUEYMIROU, W.T., PANARO, F.J., NA, E., DHARMARAJAN, K. et al. (2001). Identification of ubiquitin ligases required for skeletal muscle atrophy. Science 294: 1704-1708.

BOIX-PERALES, H., HORAN, I., WISE, H., LIN, H.R., CHUANG, L.C., YEW, P.R. and PHILPOTT, A. (2007). The E3 ubiquitin ligase skp2 regulates neural differentiation independent from the cell cycle. Neural Dev 2: 27.

CANDI, E., CIPOllONE, R., RIVETTI DI VAL CERVO, P., GONFLONI, S., MELINO, G. and KNIGHT, R. (2008). p63 in epithelial development. Cell Mol Life Sci 65: 3126-3133.

CANDI, E., TERRINONI, A., RUFINI, A., CHIKH, A., LENA, A.M., SUZUKI, Y., SAYAN, B.S., KNIGHT, R.A. and MELINO, G. (2006). p63 is upstream of IKK alpha in epidermal development. J Cell Sci 119: 4617-4622.

CARRANO, A.C., EYTAN, E., HERSHKO, A. and PAGANO, M. (1999). SKP2 is required for ubiquitin-mediated degradation of the CDK inhibitor p27. Nat Cell Biol 1: 193-199.

CHATTERJEE, A., CHANG, X., SEN, T., RAVI, R., BEDI, A. and SIDRANSKY, D. (2010). Regulation of p53 family member isoform DeltaNp63alpha by the nuclear factor-kappaB targeting kinase IkappaB kinase beta. Cancer Res 70: 10.

CHEN, A., WU, K., FUCHS, S.Y., TAN, P., GOMEZ, C. and PAN, Z.Q. (2000). The conserved RING-H2 finger of ROC1 is required for ubiquitin ligation. J Biol Chem 275: 15432-15439.

CHIANG, M.H., CHEN, L.F. and CHEN, H. (2008). Ubiquitin-conjugating enzyme UBE2D2 is responsible for FBXW2 (F-box and WD repeat domain containing 2)mediated human GCM1 (glial cell missing homolog 1) ubiquitination and degradation. Biol Reprod 79: 914-920.

CHONG, J.A., TAPIA-RAMIREZ, J., KIM, S., TOLEDO-ARAL, J.J., ZHENG, Y., BOUTROS, M.C., ALTSHULLER, Y.M., FROHMAN, M.A., KRANER, S.D. and MANDEL, G. (1995). REST: a mammalian silencer protein that restricts sodium channel gene expression to neurons. Cell 80: 949-957.

CIECHANOVER, A., ELIAS, S., HELLER, H., FERBER, S. and HERSHKO, A. (1980a). Characterization of the heat-stable polypeptide of the ATP-dependent proteolytic system from reticulocytes. J Biol Chem 255: 7525-7528.

CIECHANOVER, A., FINLEY, D. and VARSHAVSKY, A. (1984). Ubiquitin dependence of selective protein degradation demonstrated in the mammalian cell cycle mutant ts85. Cell 37: 57-66.

CIECHANOVER, A., HELLER, H., ELIAS, S., HAAS, A.L. and HERSHKO, A. (1980b). ATP-dependent conjugation of reticulocyte proteins with the polypeptide required for protein degradation. Proc Natl Acad Sci USA 77: 1365-1368.

DAVIS, R.L., WEINTRAUB, H. and LASSAR, A.B. (1987). Expression of a single transfected cDNA converts fibroblasts to myoblasts. Cell 51: 987-1000.
DESHAIES, R.J. and JOAZEIRO, C.A. (2009). RING domain E3 ubiquitin ligases. Annu Rev Biochem 78: 399-434.

DUDA, D.M., BORG, L.A., SCOTT, D.C., HUNT, H.W., HAMMEL, M. and SCHULMAN, B.A. (2008). Structural Insights into NEDD8 Activation of CullinRING Ligases: Conformational Control of Conjugation. Cell 134: 995-1006.

DUSHAY, M.S., ASLING, B. and HULTMARK, D. (1996). Origins of immunity: Relish, a compound Rel-like gene in the antibacterial defense of Drosophila. Proc Natl Acad Sci USA 93: 10343-10347.

FUCHS, S.Y., CHEN, A., XIONG, Y., PAN, Z.Q. and RONAI, Z. (1999). HOS, a human homolog of Slimb, forms an SCF complex with Skp1 and Cullin1 and targets the phosphorylation-dependent degradation of IkappaB and betacatenin. Oncogene 18: 2039-2046.

FUCHS, S.Y., SPIEGELMAN, V.S. and KUMAR, K.G. (2004). The many faces of beta-TrCP E3 ubiquitin ligases: reflections in the magic mirror of cancer. Oncogene 23: 2028-2036.

FURUKAWA, M., OHTA, T. and XIONG, Y. (2002). Activation of UBC5 ubiquitinconjugating enzyme by the RING finger of ROC1 and assembly of active ubiquitin ligases by all cullins. J Biol Chem 277: 15758-15765.

GAGNE, J.M., DOWNES, B.P., SHIU, S.H., DURSKI, A.M. and VIERSTRA, R.D. (2002). The F-box subunit of the SCF E3 complex is encoded by a diverse superfamily of genes in Arabidopsis. Proc Natl Acad Sci USA 99: 11519-11524.

GALLEGOS, J.R., LITERSKY, J., LEE, H., SUN, Y., NAKAYAMA, K., NAKAYAMA, K. and LU, H. (2008). SCF TrCP1 activates and ubiquitylates TAp63gamma. $J$ Biol Chem 283: 66-75

GEISLER, R., BERGMANN, A., HIROMI, Y. and NUSSLEIN-VOLHARD, C. (1992). cactus, a gene involved in dorsoventral pattern formation of Drosophila, is related to the I kappa B gene family of vertebrates. Cell 71: 613-621.

GOMES, M.D., LECKER, S.H., JAGOE, R.T., NAVON, A. and GOLDBERG, A.L. (2001). Atrogin-1, a muscle-specific F-box protein highly expressed during muscle atrophy. Proc Natl Acad Sci USA 98: 14440-14445.

GROSSMAN, S.R., DEATO, M.E., BRIGNONE, C., CHAN, H.M., KUNG, A.L., TAGAMI, H., NAKATANI, Y. and LIVINGSTON, D.M. (2003). Polyubiquitination of $p 53$ by a ubiquitin ligase activity of p300. Science 300: 342-344.

GU, L., ZHU, N., FINDLEY, H.W., WOODS, W.G. and ZHOU, M. (2004). Identification and characterization of the IKKalpha promoter: positive and negative regulation by ETS-1 and p53, respectively. J Biol Chem 279: 52141-52149.

GU, X., LUNDQVIST, E.N., COATES, P.J., THURFJELL, N., WETTERSAND, E. and NYLANDER, K. (2006). Dysregulation of TAp63 mRNA and protein levels in psoriasis. J Invest Dermatol 126: 137-141.

GUINEZ, C., MIR, A.-M., DEHENNAUT, V., CACAN, R., HARDUIN-LEPERS, A., MICHALSKI, J.-C. and LEFEBVRE, T. (2008). Protein ubiquitination is modulated by O-GlcNAc glycosylation. FASEB 22: 2901-2911.

GUPTA-ROSSI, N., LE BAIL, O., GONEN, H., BROU, C., LOGEAT, F., SIX, E., CIECHANOVER, A. and ISRAEL, A. (2001). Functional interaction between SEL-10, an F-box protein, and the nuclear form of activated Notch1 receptor. $J$ Biol Chem 276: 34371-34378.

HART, M., CONCORDET, J.P., LASSOT, I., ALBERT, I., DEL LOS SANTOS, R., DURAND, H., PERRET, C., RUBINFELD, B., MARGOTTIN, F., BENAROUS, R. et al. (1999). The F-box protein beta-TrCP associates with phosphorylated beta-catenin and regulates its activity in the cell. Curr Biol 9: 207-210.

HASHIMOTO, C., HUDSON, K.L. and ANDERSON, K.V. (1988). The Toll gene of Drosophila, required for dorsal-ventral embryonic polarity, appears to encode a transmembrane protein. Cell 52: 269-279.

HENKEL, T., ZABEL, U., VAN ZEE, K., MULLER, J.M., FANNING, E. and BAEUERLE, P.A. (1992). Intramolecular masking of the nuclear location signa and dimerization domain in the precursor for the p50 NF-kappa B subunit. Cell 68: 1121-1133.

HERShKO, A., CIECHANOVER, A., HELLER, H., HAAS, A.L. and ROSE, I.A. (1980). Proposed role of ATP in protein breakdown: conjugation of protein with multiple chains of the polypeptide of ATP-dependent proteolysis. Proc Natl Acad Sci USA 77: 1783-1786.

HERSHKO, A., HELLER, H., ELIAS, S. and CIECHANOVER, A. (1983). Components of ubiquitin-protein ligase system. Resolution, affinity purification, and role in protein breakdown. J Biol Chem 258: 8206-8214.

HICKE, L., SCHUBERT, H.L. and HILL, C.P. (2005). Ubiquitin-binding domains. Nat Rev Mol Cell Biol 6: 610-621. 
HO, M.S.-C., CHEN, H., CHEN, M., JACQUES, C.C., GIANGRANDE, A. and CHIEN, C.-T. (2009). Gcm protein degradation suppresses proliferation of glial progenitors. Proc Natl Acad Sci U S A 106: 6778-6783.

HOPPE, T. (2005). Multiubiquitylation by E4 enzymes: [']one size' doesn't fit all. Trends Biochem Sci 30: 183-187.

HOSOYA, T., TAKIZAWA, K., NITTA, K. and HOTTA, Y. (1995). glial cells missing: a binary switch between neuronal and glial determination in Drosophila. Cell 82: 1025-1036.

HOWARD, T.D., PAZNEKAS, W.A., GREEN, E.D., CHIANG, L.C., MA, N., ORTIZ DE LUNA, R.I., GARCIA DELGADO, C., GONZALEZ-RAMOS, M., KLINE, A.D. and JABS, E.W. (1997). Mutations in TWIST, a basic helix-loop-helix transcription factor, in Saethre-Chotzen syndrome. Nat Genet 15: 36-41.

HU, Y., BAUD, V., DELHASE, M., ZHANG, P., DEERINCK, T., ELLISMAN, M., JOHNSON, R. and KARIN, M. (1999). Abnormal morphogenesis but intact IKK activation in mice lacking the IKKalpha subunit of IkappaB kinase. Science 284: 316-320.

HUBBARD, E.J., WU, G., KITAJEWSKI, J. and GREENWALD, I. (1997). sel-10, a negative regulator of lin-12 activity in Caenorhabditis elegans, encodes a member of the CDC4 family of proteins. Genes Dev 11: 3182-3193.

HWANG, C.-S., SHEMORRY, A. and VARSHAVSKY, A. (2010). N-Terminal Acetylation of Cellular Proteins Creates Specific Degradation Signals. Science 327: 973-977.

IDE, N., HATA, Y., NISHIOKA, H., HIRAO, K., YAO, I., DEGUCHI, M., MIZOGUCHI, A., NISHIMORI, H., TOKINO, T., NAKAMURA, Y. et al. (1999). Localization of membrane-associated guanylate kinase (MAGI)-1/BAl-associated protein (BAP) 1 at tight junctions of epithelial cells. Oncogene 18: 7810-7815.

INGHAM, P.W. and MCMAHON, A.P. (2001). Hedgehog signaling in animal development: paradigms and principles. Genes Dev 15: 3059-3087.

INGHAM, P.W. and PLACZEK, M. (2006). Orchestrating ontogenesis: variations on a theme by sonic hedgehog. Nat Rev Genet 7: 841-850.

IP, Y.T., REACH, M., ENGSTROM, Y., KADALAYIL, L., CAI, H., GONZÁLEZCRESPO, S., TATEI, K. and LEVINE, M. (1993). Dif, a dorsal-related gene that mediates an immune response in Drosophila. Cell 75: 753-763.

JACQUES, C., SOUSTELLE, L., NAGY, I., DIEBOLD, C. and GIANGRANDE, A. (2009). A novel role of the glial fate determinant glial cells missing in hematopoiesis. Int J Dev Biol 53: 1013-1022.

JAIN, M., NIJHAWAN, A., ARORA, R., AGARWAL, P., RAY, S., SHARMA, P., KAPOOR, S., TYAGI, A.K. and KHURANA, J.P. (2007). F-box proteins in rice. Genome-wide analysis, classification, temporal and spatial gene expression during panicle and seed development, and regulation by light and abiotic stress. Plant Physiol 143: 1467-1483.

JIA, J., ZHANG, L., ZHANG, Q., TONG, C., WANG, B., HOU, F., AMANAI, K. and JIANG, J. (2005). Phosphorylation by double-time/CKlepsilon and CKlalpha targets cubitus interruptus for Slimb/beta-TRCP-mediated proteolytic processing. Dev Cell 9: 819-830.

JIANG, J. and STRUHL, G. (1998). Regulation of the Hedgehog and Wingless signalling pathways by the F-box/WD40-repeat protein Slimb. Nature 391: 493496.

JIN, J., SHIROGANE, T., XU, L., NALEPA, G., QIN, J., ELLEDGE, S.J. and HARPER, J.W. (2003). SCFbeta-TRCP links Chk1 signaling to degradation of the Cdc25A protein phosphatase. Genes Dev 17: 3062-3074.

JOGO, M., SHIRAISHI, S. and TAMURA, T.-A. (2009). Identification of MAFbx as a myogenin-engaged F-box protein in SCF ubiquitin ligase. FEBS Lett 583: 2715-2719.

JONES, B.W., FETTER, R.D., TEAR, G. and GOODMAN, C.S. (1995). glial cells missing: a genetic switch that controls glial versus neuronal fate. Cell 82: 10131023.

KAMURA, T., HARA, T., KOTOSHIBA, S., YADA, M., ISHIDA, N., IMAKI, H., HATAKEYAMA, S., NAKAYAMA, K. and NAKAYAMA, K.I. (2003). Degradation of p57Kip2 mediated by SCFSkp2-dependent ubiquitylation. Proc Natl Acad Sci USA 100: 10231-10236.

KANEMURA, Y., HIRAGA, S., ARITA, N., OHNISHI, T., IZUMOTO, S., MORI, K., MATSUMURA, H., YAMASAKI, M., FUSHIKI, S. and YOSHIMINE, T. (1999). Isolation and expression analysis of a novel human homologue of the Drosophila glial cells missing (gcm) gene. FEBS Lett 442: 151-156.

KARIN, M. and BEN-NERIAH, Y. (2000). Phosphorylation meets ubiquitination: the control of NF-[kappa]B activity. Annu Rev Immunol 18: 621-663.

KEPINSKI, S. and LEYSER, O. (2004). Auxin-induced SCFTIR1-Aux/IAA interaction involves stable modification of the SCFTIR1 complex. Proc Natl Acad Sci USA 101: 12381-12386.

KIM, J., JONES, B.W., ZOCK, C., CHEN, Z., WANG, H., GOODMAN, C.S. and ANDERSON, D.J. (1998). Isolation and characterization of mammalian homologs of the Drosophila gene glial cells missing. Proc Natl Acad Sci USA 95: 12364-12369.

KIM, S.Y., HERBST, A., TWORKOWSKI, K.A., SALGHETTI, S.E. and TANSEY, W.P. (2003). Skp2 regulates Myc protein stability and activity. Mol Cell11: 1177 1188.

KITAGAWA, M., LEE, S.H. and MCCORMICK, F. (2008). Skp2 suppresses p53dependent apoptosis by inhibiting p300. Mol Cell 29: 217-231.

KOSTER, M.I. and ROOP, D.R. (2004). p63 and epithelial appendage development. Differentiation 72: 364-370.

KURODA, H., TAKAHASHI, N., SHIMADA, H., SEKI, M., SHINOZAKI, K. and MATSUI, M. (2002). Classification and expression analysis of Arabidopsis Fbox-containing protein genes. Plant Cell Physiol 43: 1073-1085.

LABONNE, C. and BRONNER-FRASER, M. (2000). Snail-related transcriptional repressors are required in Xenopus for both the induction of the neural crest and its subsequent migration. Dev Biol 221: 195-205.

LAGIRAND-CANTALOUBE, J., CORNILLE, K., CSIBI, A., BATONNET-PICHON S., LEIBOVITCH, M.P. and LEIBOVITCH, S.A. (2009). Inhibition of atrogin-1/ MAFbx mediated MyoD proteolysis prevents skeletal muscle atrophy in vivo. PLoS One 4: e4973.

LAGNA, G., CARNEVALI, F., MARCHIONI, M. and HEMMATI-BRIVANLOU, A. (1999). Negative regulation of axis formation and Wnt signaling in Xenopus embryos by the F-box/WD40 protein beta TrCP. Mech Dev 80: 101-106.

LARABELL, C.A., TORRES, M., ROWNING, B.A., YOST, C., MILLER, J.R., WU, M., KIMELMAN, D. and MOON, R.T. (1997). Establishment of the dorso-ventral axis in Xenopus embryos is presaged by early asymmetries in beta-catenin that are modulated by the Wnt signaling pathway. J Cell Biol 136: 1123-1136.

LASSAR, A.B., DAVIS, R.L., WRIGHT, W.E., KADESCH, T., MURRE, C., VORONOVA, A., BALTIMORE, D. and WEINTRAUB, H. (1991). Functional activity of myogenic $\mathrm{HLH}$ proteins requires hetero-oligomerization with E12/ E47-like proteins in vivo. Cell 66: 305-315.

LATRES, E., CHIAUR, D.S. and PAGANO, M. (1999). The human F box protein beta-Trcp associates with the Cul1/Skp1 complex and regulates the stability of beta-catenin. Oncogene 18: 849-854.

LEE, J.E. (1997). Basic helix-loop-helix genes in neural development. Curr Opin Neurobiol 7: 13-20.

LI, W., WU, G. and WAN, Y. (2007). The dual effects of Cdh1/APC in myogenesis. FASEB J 21: 3606-3617.

LIN, H.R., CHUANG, L.C., BOIX-PERALES, H., PHILPOTT, A. and YEW, P.R. (2006). Ubiquitination of cyclin-dependent kinase inhibitor, Xic1, is mediated by the Xenopus F-box protein xSkp2. Cell Cycle 5: 304-314.

LIN, Y.C., BROWN, K. and SIEBENLIST, U. (1995). Activation of NF-kappa B requires proteolysis of the inhibitor I kappa $B$-alpha: signal-induced phosphorylation of I kappa B-alpha alone does not release active NF-kappa B. Proc Natl Acad Sci USA 92: 552-556.

LIU, J., FURUKAWA, M., MATSUMOTO, T. and XIONG, Y. (2002). NEDD8 Modification of CUL1 Dissociates p120CAND1, an Inhibitor of CUL1-SKP1 Binding and SCF Ligases. Mol Cell 10: 1511-1518.

LYAPINA, S.A., CORRELL, C.C., KIPREOS, E.T. and DESHAIES, R.J. (1998) Human CUL1 forms an evolutionarily conserved ubiquitin ligase complex (SCF) with SKP1 and an F-box protein. Proc Natl Acad Sci USA 95: 7451-7456.

MANIATIS, T. (1999). A ubiquitin ligase complex essential for the NF-kappaB, Wnt/ Wingless, and Hedgehog signaling pathways. Genes Dev 13: 505-510.

MANTOVANI, F. and BANKS, L. (2003). Regulation of the discs large tumor suppressor by a phosphorylation-dependent interaction with the beta-TrCP ubiquitin ligase receptor. J Biol Chem 278: 42477-42486.

MANTOVANI, F., MASSIMI, P. and BANKS, L. (2001). Proteasome-mediated regulation of the hDIg tumour suppressor protein. J Cell Sci 114: 4285-4292.

MAO, J.H., PEREZ-LOSADA, J., WU, D., DELROSARIO, R., TSUNEMATSU, R., NAKAYAMA, K.I., BROWN, K., BRYSON, S. and BALMAIN, A. (2004). Fbxw7/ 
Cdc4 is a p53-dependent, haploinsufficient tumour suppressor gene. Nature 432: 775-779.

MARIKAWA, Y. and ELINSON, R.P. (1998). beta-TrCP is a negative regulator of Wnt/beta-catenin signaling pathway and dorsal axis formation in Xenopus embryos. Mech Dev 77: 75-80.

MILLS, A.A., ZHENG, B., WANG, X.J., VOGEL, H., ROOP, D.R. and BRADLEY, A. (1999). p63 is a p53 homologue required for limb and epidermal morphogenesis. Nature 398: 708-713.

NAKAYAMA, K., NAGAHAMA, H., MINAMISHIMA, Y.A., MATSUMOTO, M., NAKAMICHI, I., KITAGAWA, K., SHIRANE, M., TSUNEMATSU, R., TSUKIYAMA, T., ISHIDA, N. et al. (2000). Targeted disruption of Skp2 results in accumulation of cyclin $E$ and p27(Kip1), polyploidy and centrosome overduplication. EMBO J 19: 2069-2081.

NURSE, P., THURIAUX, P. and NASMYTH, K. (1976). Genetic control of the cell division cycle in the fission yeast Schizosaccharomyces pombe. Mol Gen Genet 146: 167-178.

O'NEIL, J., GRIM, J., STRACK, P., RAO, S., TIBBITTS, D., WINTER, C., HARDWICK, J., WELCKER, M., MEIJERINK, J.P., PIETERS, R. et al. (2007). FBW7 mutations in leukemic cells mediate NOTCH pathway activation and resistance to gamma-secretase inhibitors. J Exp Med 204: 1813-1824.

OHTA, T., MICHEL, J.J., SCHOTTELIUS, A.J. and XIONG, Y. (1999). ROC1, a homolog of APC11, represents a family of cullin partners with an associated ubiquitin ligase activity. Mol Cell 3: 535-541.

ONOYAMA, I., TSUNEMATSU, R., MATSUMOTO, A., KIMURA, T., DE ALBORAN, I.M., NAKAYAMA, K. and NAKAYAMA, K.I. (2007). Conditional inactivation of Fbxw7 impairs cell-cycle exit during $\mathrm{T}$ cell differentiation and results in lymphomatogenesis. J Exp Med 204: 2875-2888.

PAN, Y., BAI, C.B., JOYNER, A.L. and WANG, B. (2006). Sonic hedgehog signaling regulates $\mathrm{Gli} 2$ transcriptional activity by suppressing its processing and degradation. Mol Cell Biol 26: 3365-3377.

PETROSKI, M.D. and DESHAIES, R.J. (2005). Mechanism of lysine 48-linked ubiquitin-chain synthesis by the cullin-RING ubiquitin-ligase complex SCFCdc34. Cell 123: 1107-1120.

PICKART, C.M. and COHEN, R.E. (2004). Proteasomes and their kin: proteases in the machine age. Nat Rev Mol Cell Biol 5: 177-187.

PICKART, C.M. and ROSE, I.A. (1985). Functional heterogeneity of ubiquitin carrier proteins. J Biol Chem 260: 1573-1581.

REAVIE, L., GATTA, G.D., CRUSIO, K., ARANDA-ORGILLES, B., BUCKLEY, S.M., THOMPSON, B., LEE, E., GAO, J., BREDEMEYER, A.L., HELMINK, B.A. et al. (2010). Regulation of hematopoietic stem cell differentiation by a single ubiquitin ligase-substrate complex. Nat Immunol 11: 207-215.

REUVER, S.M. and GARNER, C.C. (1998). E-cadherin mediated cell adhesion recruits SAP97 into the cortical cytoskeleton. J Cell Sci 111: 1071-1080.

REYNAUD, E.G., LEIBOVITCH, M.P., TINTIGNAC, L.A.J., PELPEL, K., GUILLIER, M. and LEIBOVITCH, S.A. (2000). Stabilization of MyoD by Direct Binding to p57Kip2. J Biol Chem 275: 18767-18776.

SCHOENHERR, C.J. and ANDERSON, D.J. (1995). The neuron-restrictive silencer factor (NRSF): a coordinate repressor of multiple neuron-specific genes. Science 267: 1360-1363.

SCHREIBER, J., RIETHMACHER-SONNENBERG, E., RIETHMACHER, D., TUERK, E.E., ENDERICH, J., BOSL, M.R. and WEGNER, M. (2000). Placental failure in mice lacking the mammalian homolog of glial cells missing, GCMa. $\mathrm{Mol}$ Cell Biol 20: 2466-2474.

SCHULMAN, B.A., CARRANO, A.C., JEFFREY, P.D., BOWEN, Z., KINNUCAN, E.R., FINNIN, M.S., ELLEDGE, S.J., HARPER, J.W., PAGANO, M. and PAVLETICH, N.P. (2000). Insights into SCF ubiquitin ligases from the structure of the Skp1-Skp2 complex. Nature 408: 381-386.

SEMPLE, C.A. (2003). The comparative proteomics of ubiquitination in mouse. Genome Res 13: 1389-1394.

SEN, R. and BALTIMORE, D. (1986). Inducibility of [kappa] immunoglobulin enhancer-binding protein NF-[kappa]B by a posttranslational mechanism. Cell 47: $921-928$

SEO, E., KIM, H., KIM, R., YUN, S., KIM, M., HAN, J.-K., COSTANTINI, F. and JHO, E.-H. (2009). Multiple isoforms of [beta]-TrCP display differential activities in the regulation of Wnt signaling. Cellular Signalling 21: 43-51.
SIGNORETTI, S., DI MARCOTULLIO, L., RICHARDSON, A., RAMASWAMY, S., ISAAC, B., RUE, M., MONTI, F., LODA, M. and PAGANO, M. (2002). Oncogenic role of the ubiquitin ligase subunit Skp2 in human breast cancer. $J$ Clin Invest 110: 633-641.

SIL, A.K., MAEDA, S., SANO, Y., ROOP, D.R. and KARIN, M. (2004). IkappaB kinase-alpha acts in the epidermis to control skeletal and craniofacial morphogenesis. Nature 428: 660-664.

SKAAR, J.R., D'ANGIOLELLA, V., PAGAN, J.K. and PAGANO, M. (2009a). SnapShot: F Box Proteins II. Cell 137: 1358.e1351-1358.e1352.

SKAAR, J.R., PAGAN, J.K. and PAGANO, M. (2009b). SnapShot: F Box Proteins I. Cell 137: 1160-1160.e1161.

SKAAR, J.R. and PAGANO, M. (2009). Control of cell growth by the SCF and APC/ $\mathrm{C}$ ubiquitin ligases. Current Opinion in Cell Biology 21: 816-824.

SMELKINSON, M.G., ZHOU, Q. and KALDERON, D. (2007). Regulation of CiSCFSlimb binding, Ci proteolysis, and hedgehog pathway activity by Ci phosphorylation. Dev Cell 13: 481-495

STEWARD, R. (1987). Dorsal, an embryonic polarity gene in Drosophila, is homologous to the vertebrate proto-oncogene, c-rel. Science 238: 692-694.

SUZUKI, H., CHIBA, T., KOBAYASHI, M., TAKEUCHI, M., SUZUKI, T., ICHIYAMA, A., IKENOUE, T., OMATA, M., FURUICHI, K. and TANAKA, K. (1999). IkappaBalpha ubiquitination is catalyzed by an SCF-like complex containing Skp1, cullin-1, and two F-box/WD40-repeat proteins, betaTrCP1 and betaTrCP2 Biochem Biophys Res Commun 256: 127-132.

TAKEDA, K., TAKEUCHI, O., TSUJIMURA, T., ITAMI, S., ADACHI, O., KAWAI, T., SANJO, H., YOSHIKAWA, K., TERADA, N. and AKIRA, S. (1999). Limb and skin abnormalities in mice lacking IKKalpha. Science 284: 313-316.

TAN, X., CALDERON-VILLALOBOS, L.I., SHARON, M., ZHENG, C., ROBINSON, C.V., ESTELLE, M. and ZHENG, N. (2007). Mechanism of auxin perception by the TIR1 ubiquitin ligase. Nature 446: 640-645.

TETZLAFF, M.T., YU, W., LI, M., ZHANG, P., FINEGOLD, M., MAHON, K., HARPER, J.W., SCHWARTZ, R.J. and ELLEDGE, S.J. (2004). Defective cardiovascular development and elevated cyclin $E$ and Notch proteins in mice lacking the Fbw7 F-box protein. Proc Natl Acad Sci USA 101: 3338-3345.

TINTIGNAC, L.A., LAGIRAND, J., BATONNET, S., SIRRI, V., LEIBOVITCH, M.P. and LEIBOVITCH, S.A. (2005). Degradation of MyoD mediated by the SCF (MAFbx) ubiquitin ligase. J Biol Chem 280: 2847-2856.

VERNON, A.E., DEVINE, C. and PHILPOTT, A. (2003). The cdk inhibitor p27Xic1 is required for differentiation of primary neurones in Xenopus. Development 130: 85-92.

VERNON, A.E. and LABONNE, C. (2006). Slug stability is dynamically regulated during neural crest development by the F-box protein Ppa. Development 133: 3359-3370.

VERNON, A.E. and PHILPOTT, A. (2003). A single cdk inhibitor, p27Xic1, functions beyond cell cycle regulation to promote muscle differentiation in Xenopus. Development 130: 71-83.

VON DER LEHR, N., JOHANSSON, S., WU, S., BAHRAM, F., CASTELL, A., CETINKAYA, C., HYDBRING, P., WEIDUNG, I., NAKAYAMA, K., NAKAYAMA, K.I. et al. (2003). The F-box protein Skp2 participates in c-Myc proteosomal degradation and acts as a cofactor for c-Myc-regulated transcription. Mol Cell 11: 1189-1200.

WANG, B. and LI, Y. (2006). Evidence for the direct involvement of \{beta\}TrCP in Gli3 protein processing. Proc Natl Acad Sci USA 103: 33-38.

WEI, W., AYAD, N.G., WAN, Y., ZHANG, G.J., KIRSCHNER, M.W. and KAELIN W.G., JR. (2004). Degradation of the SCF component Skp2 in cell-cycle phase G1 by the anaphase-promoting complex. Nature 428: 194-198.

WESTBROOK, T.F., HU, G., ANG, X.L., MULLIGAN, P., PAVLOVA, N.N., LIANG, A., LENG, Y., MAEHR, R., SHI, Y., HARPER, J.W. et al. (2008). SCFbeta-TRCP controls oncogenic transformation and neural differentiation through REST degradation. Nature 452: 370-374.

WILKINSON, K.D., URBAN, M.K. and HAAS, A.L. (1980). Ubiquitin is the ATPdependent proteolysis factor I of rabbit reticulocytes. J Biol Chem 255: 75297532.

WINSTON, J.T., STRACK, P., BEER-ROMERO, P., CHU, C.Y., ELLEDGE, S.J. and HARPER, J.W. (1999). The SCFbeta-TRCP-ubiquitin ligase complex associates specifically with phosphorylated destruction motifs in IkappaBalpha and beta-catenin and stimulates IkappaBalpha ubiquitination in vitro. Genes 
Dev 13: 270-283

WOLF, D.H. and HILT, W. (2004). The proteasome: a proteolytic nanomachine of cell regulation and waste disposal. Biochim Biophys Acta 1695: 19-31.

WOODS, D.F., HOUGH, C., PEEL, D., CALLAINI, G. and BRYANT, P.J. (1996). DIg protein is required for junction structure, cell polarity, and proliferation control in Drosophila epithelia. J Cell Biol 134: 1469-1482.

WU, G., LYAPINA, S., DAS, I., LI, J., GURNEY, M., PAULEY, A., CHUI, I., DESHAIES, R.J. and KITAJEWSKI, J. (2001). SEL-10 is an inhibitor of notch signaling that targets notch for ubiquitin-mediated protein degradation. Mol Cell Biol 21: 7403-7415.

WU, G., XU, G., SCHULMAN, B.A., JEFFREY, P.D., HARPER, J.W. and PAVLETICH, N.P. (2003). Structure of a beta-TrCP1-Skp1-beta-catenin complex: destruction motif binding and lysine specificity of the SCF(beta-TrCP1) ubiquitin ligase. Mol Cell 11: 1445-1456.

WU, K., FUCHS, S.Y., CHEN, A., TAN, P., GOMEZ, C., RONAI, Z. and PAN, Z.Q. (2000). The SCF(HOS/beta-TRCP)-ROC1 E3 ubiquitin ligase utilizes two distinct domains within CUL1 for substrate targeting and ubiquitin ligation. $\mathrm{Mol}$ Cell Biol 20: 1382-1393.

WU, L.P. and ANDERSON, K.V. (1998). Regulated nuclear import of Rel proteins in the Drosophila immune response. Nature 392: 93-97.

WULCZYN, F.G., KRAPPMANN, D. and SCHEIDEREIT, C. (1998). Signal-dependent degradation of IkappaBalpha is mediated by an inducible destruction box that can be transferred to NF-kappaB, bcl-3 or p53. Nucleic Acids Res 26: 17241730.
YANG, A., SCHWEITZER, R., SUN, D., KAGHAD, M., WALKER, N., BRONSON R.T., TABIN, C., SHARPE, A., CAPUT, D., CRUM, C. et al. (1999). p63 is essential for regenerative proliferation in limb, craniofacial and epithelial development. Nature 398: 714-718.

YE, X., NALEPA, G., WELCKER, M., KESSLER, B.M., SPOONER, E., QIN, J., ELLEDGE, S.J., CLURMAN, B.E. and HARPER, J.W. (2004). Recognition of Phosphodegron Motifs in Human Cyclin E by the SCFFbw7 Ubiquitin Ligase. $J$ Biol Chem 279: 50110-50119.

YOOK, J.I., LI, X.Y., OTA, I., FEARON, E.R. and WEISS, S.J. (2005). Wntdependent regulation of the E-cadherin repressor snail. J Biol Chem 280: 11740-11748.

ZENG, Z., WANG, W., YANG, Y., CHEN, Y., YANG, X., DIEHL, J.A., LIU, X. and LEI, M. (2010). Structural Basis of Selective Ubiquitination of TRF1 by SCFFbx4. Dev Cell 18: 214-225.

ZHANG, P., WONG, C., LIU, D., FINEGOLD, M., HARPER, J.W. and ELLEDGE, S.J. (1999). p21(CIP1) and p57(KIP2) control muscle differentiation at the myogenin step. Genes Dev 13: 213-224.

ZHENG, N., SCHULMAN, B.A., SONG, L., MILLER, J.J., JEFFREY, P.D., WANG, P., CHU, C., KOEPP, D.M., ELLEDGE, S.J., PAGANO, M. et al. (2002). Structure of the Cul1-Rbx1-Skp1-F boxSkp2 SCF ubiquitin ligase complex. Nature 416: 703-709.

ZHOU, B.P., DENG, J., XIA, W., XU, J., LI, Y.M., GUNDUZ, M. and HUNG, M.C. (2004). Dual regulation of Snail by GSK-3beta-mediated phosphorylation in control of epithelial-mesenchymal transition. Nat Cell Biol 6: 931-940. 


\section{Further Related Reading, published previously in the Int. J. Dev. Biol.}

Patterning and cell fate in ear development

Berta Alsina, Fernando Giraldez and Cristina Pujades

Int. J. Dev. Biol. (2009) 53: 1503-1513

A novel role of the glial fate determinant glial cells missing in hematopoiesis

Cécile Jacques, Laurent Soustelle, István Nagy, Céline Diebold and Angela Giangrande

Int. J. Dev. Biol. (2009) 53: 1013-1022

Fate of cranial neural crest cells during craniofacial development in endothelin-A receptor-deficient mice Makoto Abe, Louis-Bruno Ruest and David E. Clouthier

Int. J. Dev. Biol. (2007) 51: 97-105

The fate of larval flagellated cells during metamorphosis of the sponge Halisarca dujardini

Yulia I. Mukhina, Vadim V. Kumeiko, Olga I. Podgornaya and Sofia M. Efremova

Int. J. Dev. Biol. (2006) 50: 533-541

Heparan sulfates isolated from adult neural progenitor cells can direct phenotypic maturation Hiram Chipperfield, Kuldip S Bedi, Simon M Cool and Victor Nurcombe Int. J. Dev. Biol. (2002) 46: 661-670

The CNS midline cells control the spitz class and Egfr signaling genes to establish the proper cell fate of the Drosophila ventral neuroectoderm

J Chang, I O Kim, J S Ahn and S H Kim

Int. J. Dev. Biol. (2001) 45: 715-724

The role of stem cell factor and of alternative c-kit gene products in the establishment, maintenance and function of germ cells C Sette, S Dolci, R Geremia and P Rossi

Int. J. Dev. Biol. (2000) 44: 599-608

Regulation of primordial germ cell development in the mouse M De Felici

Int. J. Dev. Biol. (2000) 44: 575-580

Nerve growth factor induced neurite outgrowth from amphibian neuroepithelial precursor cells is prevented by dipeptides inhibiting ubiquitin-mediated proteolysis

J P Maufroid, R A Bradshaw, B Boilly and H Hondermarck

Int. J. Dev. Biol. (1996) 40: 609-611

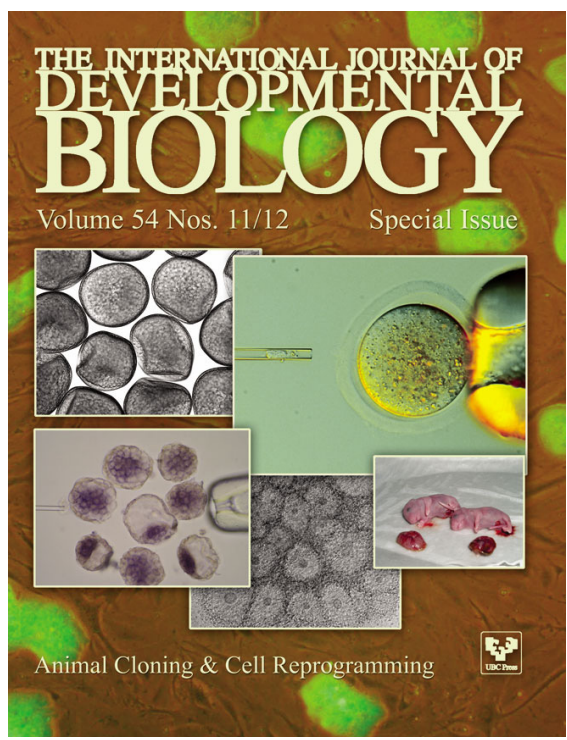

5 yr ISI Impact Factor $(2009)=3.253$

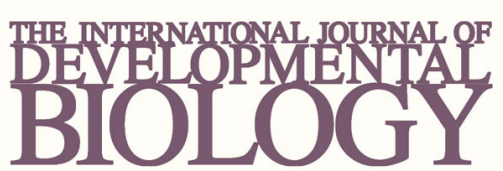

Volume 54 Nos. 6/7
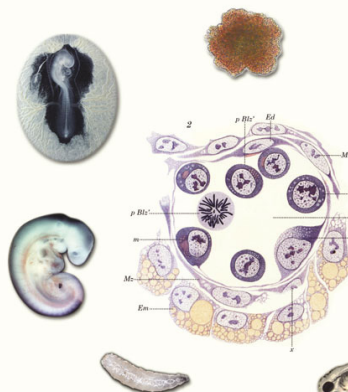

Special Issue

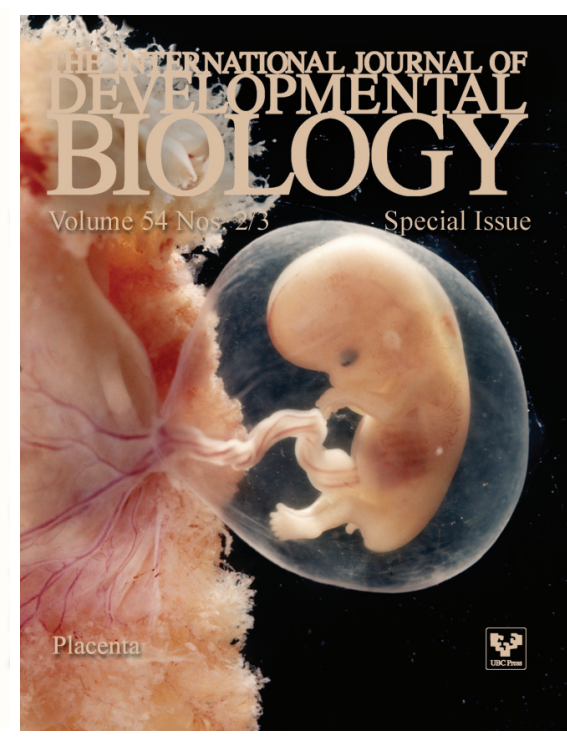

